\title{
Estimation of genetic progress after eight cycles of recurrent selection for common bean grain yield
}

\author{
Graciele Simoneti da Silva ${ }^{1 *}$ Magno Antonio Patto Ramalho ${ }^{1}$, Ângela de Fátima Barbosa Abreu ${ }^{2}$ and José Airton Rodrigues Nunes ${ }^{1}$
}

Received 3 April 2010

Accepted 8 July 2010

\begin{abstract}
The objective of this study was to estimate the genetic progress of eight cycles of recurrent selection for common bean lines with high yield. The base population was obtained from 10 parents differing in several characters. To date, eight selection cycles have been performed. In each cycle the selection process continues after recombination, until lines are established, which are then evaluated more extensively in the experiment of evaluation of elite lines together with lines of other programs. The genetic progress was estimated based on the data of evaluations of these lines in each cycle over the years. The estimated genetic progress of $3.3 \%$ per cycle allows the conclusion that recurrent selection for grain yield is efficient.
\end{abstract}

Key words: plant breeding, quantitative genetics, Phaseolus vulgaris $L$.

\section{INTRODUCTION}

Most traits of economic importance breeders work are polygenic. This means that it is virtually impossible to accumulate all favorable alleles in a line all at once. The solution is to accumulate these favorable alleles stepwise or to use recurrent selection. In this case, the best plants and/or families are recombined with each selection cycle. It is hoped thereby to increase the frequency of genotypically superior plants in the population without reducing the genetic variability (Ramalho et al. 2001, Hallauer 1992).

The use of recurrent selection was proposed for allogamous plants some decades ago. In the case of autogamous plants, the use is more recent, but widespread for various species such as wheat (Wang et al. 1996), rice (Rangel et al. 1998), oats (Koeyer et al. 1993), and soybean
(Wilcox 1998). For common bean, there is a number of reports on the use of recurrent selection to improve several traits, e.g., plant architecture (Menezes Junior et al. 2008), pathogen resistance (Amaro et al. 2007), crop cycle (Silva et al. 2007), and grain yield (Ramalho et al. 2005).

In Brazil, the prevailing bean grain type is carioca, i.e., beige with brown stripes. This kind of beans came on the market in 1969 (Almeida et al. 1971) and as the acceptance has increased since then, breeding programs have largely focused on developing lines with this grain type (Ramalho and Abreu 2006).

At the Federal University of Lavras (UFLA), a recurrent selection program with common bean was conducted to increase yields as of 1990. After the identification of the best progenies in each selection cycle, selection continued until lines were established. These

\footnotetext{
${ }^{1}$ Universidade Federal de Lavras, Departamento de Biologia, C.P. 3.037, 37.200-000, Lavras, MG, Brazil. *E-mail: g_simoneti@hotmail.com.

${ }^{2}$ Embrapa Arroz e Feijão, Rod. Goiânia, Nova Veneza, km 12, C.Postal 179, 75.375-000, Santo Antônio de Goiás, GO, Brazil.
} 
were assessed over the years, along with lines from other programs in the subsequent growing seasons, before being tested in the experiments of value for cultivation and use (VCU).

The success of recurrent selection is evaluated by the estimated genetic progress. In the case of autogamous plants, there are several possibilities to obtain this estimate (Ramalho et al. 2005). The progress in selection of the population of the recurrent selection program of UFLA was estimated at $4.3 \%$ in the first four cycles (Ramalho et al. 2005). The methodology used an experiment in which the top five lines of each cycle were evaluated simultaneously, all seeds recently propagated in one growing season. Another option, still little explored, is to use evaluation data of the lines obtained in each cycle. The advantage of this procedure is that no additional experiment is required.

In this context, the purpose of this study was to estimate the genetic gain for grain yield of carioca type in the recurrent selection program for common bean of UFLA after eight selection cycles, using data from evaluations of lines in each cycle over the years.

\section{MATERIAL AND METHODS}

Data of a recurrent selection program of UFLA (Federal University of Lavras), initiated in 1990, were used. The base population had been obtained from the lines shown in Table 1 . These lines were crossed and $F_{1}$ seeds obtained from the following hybrids: BAT $477 \mathrm{x}$ IAPAR 14, FT 84-292 x BAT 477, Jalo x A-252, A-77 x Ojo de Liebre, ESAL 645 x Jalo, Pintado x BAT 477, BAT 477 x Carioca, IAPAR $14 \times$ Pintado and ESAL $645 \times$ A
252. Subsequently, double-cross hybrids were obtained. One hundred and fifty seeds of the $\mathrm{F}_{2}$ hybrids of different double-cross hybrids with better grain type were mixed to obtain the population of the first cycle (C-I), the $\mathrm{S}_{0}$ generation.

The $S_{0: 1}$ progenies were obtained and evaluated in Lavras. Subsequently, the best $S_{0: 2}$ progenies were evaluated at two or more locations, with more replications. The best $\mathrm{S}_{0: 3}$ progenies were recombined. The process of evaluating recombinant and various other progenies continued until the establishment of inbred lines $\left(\mathrm{S}_{0: 8}\right)$. This process was repeated until the eighth cycle (C-VIII).

The best lines of each cycle were evaluated in the test of elite lines of the UFLA breeding program. The experiments usually have 25 to 36 lines. Part of these lines is derived from the recurrent selection mentioned above and the others from other selection programs. Three common control cultivars Carioca, Carioca MG and Ouro Negro were also included. The plots consisted of two 4-m rows with 15 seeds per meter. The experiments were assessed at several locations, however, only the data obtained in Lavras were used. Seeds were sown for the three growing seasons in which common bean is usually grown in Minas Gerais, that is, in February, July and November. The management and cultural practices were those regionally recommended for the crop. In the growing seasons of February and July, the experiments were irrigated to complement rainfall. The lines of each cycle were evaluated for two years.

The grain yield data (in $\mathrm{kg} \mathrm{ha}^{-1}$ ) were evaluated in a randomized block design, involving only lines of the recurrent selection and the three controls, and were subjected to analysis of variance per growing season and

Table 1. Some traits of the common bean lines used in the base population of the recurrent selection program of UFLA

\begin{tabular}{|c|c|c|c|c|}
\hline Lines & Origin & Race & Growth habit $^{1}$ & Grain type \\
\hline BAT 477 & CIAT & Mesoamérica & II & Beige \\
\hline IAPAR 14 & IAPAR & Mesoamérica & III & Beige with brown stripes \\
\hline FT 84-292 & FT Sementes & Mesoamérica & II & Beige with brown stripes \\
\hline Jalo & EPAMIG & Nova Granada & III & Yellow \\
\hline A-252 & CIAT & Mesoamérica & III & Beige with brown stripes \\
\hline A-77 & CIAT & Mesoamérica & I & Beige with brown stripes \\
\hline Ojo de Liebre & CIAT & Durango & III & Beige with brown stripes \\
\hline ESAL 645 & UFLA & Mesoamérica & II & Beige with brown stripes \\
\hline Pintado & UFLA & Nova Granada & III & Striped \\
\hline Carioca & IAC & Mesoamérica & III & Beige with brown stripes \\
\hline
\end{tabular}

${ }^{1}$ Type I: Determinate growth habit; Type II, III and IV: Indeterminate growth habit. 
cycle. Subsequently, a combined analysis was performed involving all cycles using the following model and considering all effects as fixed, except block and error:

$$
\mathrm{Y}_{\mathrm{ijkl}}=\mu+\mathrm{c}_{1}+\mathrm{s}_{(\mathrm{k}) 1}+\mathrm{b}_{\mathrm{j}(\mathrm{kl})}+\mathrm{l}_{\mathrm{i}}+\mathrm{lc}_{\mathrm{i} 1}+\mathrm{ls}_{\mathrm{ik}(\mathrm{l})}+\mathrm{e}_{(\mathrm{ijkl})}
$$

where:

$\mathrm{Y}_{\mathrm{ijkl}}=$ observation of line $i$ in block $j$, in the growing season $k$, in cycle $1 ; \mu=$ general mean; $c_{l}=$ effect of cycle $l ; s_{(k) l}=$ effect of growing season $k$ in cycle $l ; b_{j(k l)}=$ effect of block $j$ in growing season $k$, in cycle $l ; l_{i}=$ effect of line $\mathrm{i}$ (includes the lines of each cycle and the common controls); $l c_{i l}=$ effect of interaction lines $\mathrm{x}$ cycles (includes only the common controls); $l s_{i k(l)}=$ interaction of line $\mathrm{x}$ growing season in the cycle (includes the lines of each cycle and the common controls); and $e_{(i j k l)}=$ experimental error associated with $Y_{i j k l}$. All tests were performed using SAS (SAS Institute 2000).

To estimate the genetic progress, the adjusted means were used for all lines, except the common control of each cycle. The linear regression equation was adjusted between the independent variable, number of selection cycles $(x=$ $1,2, \ldots, 8)$ and the dependent variable, the mean grain yield of the lines of each cycle $(y)$. The percentage gain or genetic progress per cycle (PG\%) was estimated by the following expression: $P G=\left(b_{1} / b_{0}\right) * 100$, where $b_{1}$ is the estimated of the linear regression coefficient or absolute gain per cycle and $b_{0}$ is the estimated intercept or mean grain yield in cycle zero $\left(C_{0}\right)$.

\section{RESULTS AND DISCUSSION}

It was decided to estimate the genetic progress of the experiments conducted in Lavras only because until the establishment of the lines most progenies were assessed there. In total, data from 42 experiments in two years, in eight selection cycles were used. The number of experiments should be 48 , however, six were not included because they were not conducted in the determined growing seasons and years or because the data were lost due to some climate problem.

To get a good estimate of the genetic progress in lines obtained at the end of each cycle, the efficiency of selection until the establishment of the lines must be similar in the different cycles. Since the basic process of conducting the progenies was very similar, differing only in the number of progenies evaluated in each generation, it was concluded that the estimate obtained is reliable.

In the analysis of variance of the lines from each selection cycle and also of the three controls, the differences between lines were significant $(\mathrm{P} \leq 0.05)$, except in the lines derived from cycle VI, indicating that there was still variability between the lines at the end of the process. The difference between yields in all cycles was also significant $(\mathrm{P} \leq 0.001)$ as well as for the interaction line $\mathrm{x}$ growing season, except in the cycles I, V and VII (Table 2). The occurrence of line $x$ growing season interaction in common bean is often reported. It was observed that this interaction is even more pronounced than that of line $\mathrm{x}$ location (Carneiro et al. 2002, Matos et al. 2007).

The summary of combined variance of the lines of all cycles showed significant differences between cycles, growing seasons, lines, and the interactions of line $\mathrm{x}$ cycle and line $\mathrm{x}$ growing season/cycle (Table 3 ). The line $\mathrm{x}$ cycle interaction showed that the mean performance of the controls was not coincident in the different cycles. Thus, more than one control is needed in such studies for a better adjustment of the performance of the lines obtained in different cycles. In this study, the controls were two cultivars with carioca grain ('Carioca' and 'Carioca MG') and one with black grain ('Ouro Negro'), all recommended for the region during most of the evaluation period.

A slight tendency to increase the mean of lines in each cycle was observed throughout the cycles (Table 4). The regression coefficient $\left(b_{1}\right)$ between the independent variable number of cycles and the dependent variable mean of cycles was $b_{1}=68.58$ (Figure 1 ). As reference to estimate the genetic progress (in \%) the value of the intercept of the regression was used instead of the mean of the lines from the first cycle, because the lines of cycle I had already been derived from a selection cycle. The value of the intercept of the regression would correspond to the mean of the lines in cycle 0 . This would be as if the mean of the 10 parent lines were used (Table 1), with which the selection program had been initiated. This indicates that the increase in the mean of the lines with recurrent selection was $68.58 \mathrm{~kg} \mathrm{ha}^{-1}$ per cycle, i.e., a gain of $3.3 \%$ per cycle.

It could be argued that, as the number of lines obtained at the end of each cycle was different (Table 4), the estimated progress could be influenced by this difference. To prove this fact, the progress was estimated based on a random sample of six lines per cycle. It was observed that the estimate of $b_{1}$ (Figure 2) was very similar to that obtained when considering a different number of lines to obtain the mean of each cycle (Figure 1).

The magnitude of the estimated progress with recurrent 
GS Silva et al.

Table 2. Summary of the analysis of variance of grain yield $\left(\mathrm{kg} \mathrm{ha}^{-1}\right)$ per cycle, including all lines derived from the program of recurrent selection for common bean yield

\begin{tabular}{|c|c|c|c|c|c|}
\hline \multirow{2}{*}{ Cycles } & \multicolumn{3}{|c|}{ Mean Square } & \multirow{2}{*}{ Mean } & \multirow{2}{*}{$R^{2}(\%)^{1}$} \\
\hline & Growing season (S) & Line (L) & $\mathbf{S} \times \mathbf{L}$ & & \\
\hline I & $7627207.4^{*}$ & $447834.6^{*}$ & 272924.2 & 1873 & 73.10 \\
\hline II & $35599100.6^{*}$ & $1141439.2 *$ & $352734.4^{*}$ & 2152 & 85.31 \\
\hline III & $15152533.3^{*}$ & $710535.9^{*}$ & $261653.9^{*}$ & 2414 & 84.54 \\
\hline IV & $10827329.7^{*}$ & $438791.2^{*}$ & $2148976^{* *}$ & 3086 & 83.66 \\
\hline $\mathrm{V}$ & $11270397.9^{*}$ & $223299.9 *$ & 154266.6 & 2415 & 78.99 \\
\hline VI & $2600414.7^{*}$ & $271014.5^{* *}$ & $410323.1 * *$ & 2563 & 51.88 \\
\hline VII & $1442805.4^{*}$ & $347292.5^{*}$ & 207331.6 & 2475 & 52.31 \\
\hline VIII & $5473329.3^{*}$ & $813884.0^{*}$ & $383930.0^{*}$ & 2052 & 71.87 \\
\hline
\end{tabular}

${ }^{1}$ Coefficient of determination of the statistical model.

$*, * *$ : significant at $5 \%$ and $1 \%$ probability, respectively, by the $\mathrm{F}$ test.

Table 3. Analysis of variance of grain yield $\left(\mathrm{kg} \mathrm{ha}^{-1}\right)$ involving all lines derived from the eight recurrent selection cycles of common bean

\begin{tabular}{lrrr}
\hline Source of variation & df & MS & Pr $>$ F \\
\hline Cycles & 7 & 8505125.5 & $<0.0001$ \\
Growing seasons/cycle & 34 & 11741859.2 & $<0.0001$ \\
Blocks/growing seasons/cycle & 82 & 211177.3 & 0.1761 \\
Lines & 80 & 595641.9 & $<0.0001$ \\
Lines x cycles & 14 & 326795.1 & 0.0367 \\
Lines x growing seasons/cycle & 395 & 293019.8 & $<0.0001$ \\
Error & 910 & 183171.006 & \\
\hline Mean & \multicolumn{4}{c}{2346.40} \\
$\mathrm{R}^{2}(\%)$ & 82.10 \\
CV $(\%)$ & \multicolumn{4}{c}{18.24} \\
\hline
\end{tabular}

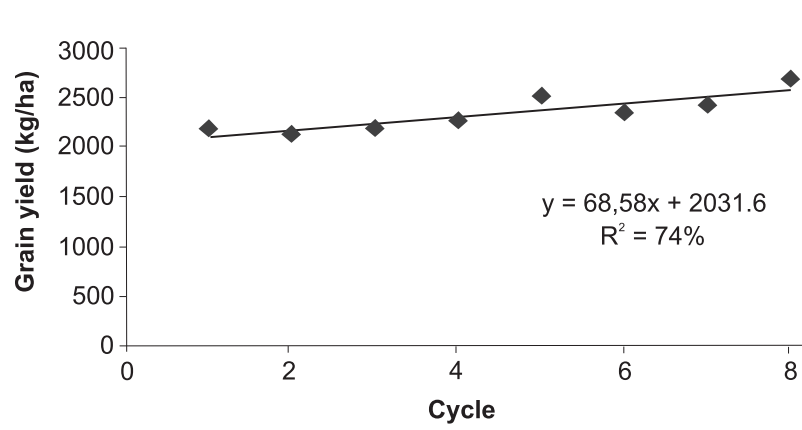

Figure 1. Response of grain yield $\left(\mathrm{kg} \mathrm{ha}^{-1}\right)$ of common bean lines in each selection cycle.

selection for common bean grain yield was similar as in other situations, in which however a lower number of cycles was evaluated (Singh et al. 1999) and lower than that reported by Ranalli (1996 ) and Barron et al. (1999). It is noteworthy that these authors used the progeny means of $\mathrm{S}_{0: 1}$ and $\mathrm{S}_{0: 2}$ as reference, besides evaluating a smaller number of
Table 4. Mean grain yield $\left(\mathrm{kg} \mathrm{ha}^{-1}\right)$ of common bean lines in eight cycles of recurrent selection, adjusted for the controls

\begin{tabular}{cccc}
\hline Cycles & Mean of lines & Mean of controls & No. lines/cycle \\
\hline I & 2186 & 2030 & 8 \\
II & 2125 & 2329 & 18 \\
III & 2180 & 2584 & 9 \\
IV & 2263 & 3183 & 6 \\
V & 2517 & 2328 & 10 \\
VI & 2341 & 2612 & 10 \\
VII & 2416 & 2466 & 10 \\
VIII & 2696 & 1840 & 7 \\
\hline
\end{tabular}

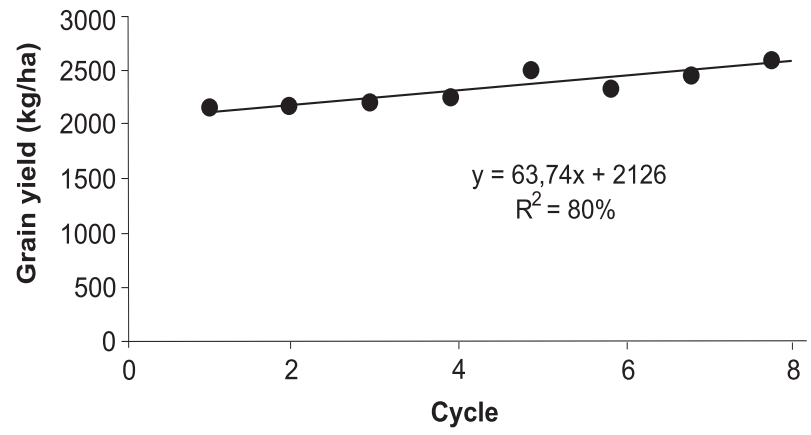

Figure 2. Response of grain yield $\left(\mathrm{kg} \mathrm{ha}^{-1}\right)$ of six random common bean lines in each selection cycle.

cycles. The genetic progress by recurrent selection for grain yield was obtained in other species of autogamous plants, such as soybean (Sumarno and Fehr, 1982, Werner and Wilcox 1990).

The genetic progress of this program was estimated 
by Ramalho et al. (2005). Selection progress was $4.3 \%$ in the first four cycles. The methodology used an experiment in which the top five lines of each cycle were evaluated simultaneously, all seeds recently propagated in a growing season. The procedure used here, besides not requiring any additional experiments, estimated the progress based on the adjusted means as related to the controls. The estimate of genetic progress can be considered similar in both conditions.

Recurrent selection was shown to be efficient and in the future lines with increasing grain yield may be obtained if the program continues. The estimate of genetic progress of $3.3 \%$ per cycle allows the conclusion that recurrent selection for grain yield is efficient. The genetic progress in the eighth cycle was estimated at $26.4 \%$.

\section{ACKNOWLEDGEMENTS}

The authors wish to thank the CNPq for the doctoral fellowship of the first author and for research grants of the second and third author.

\title{
Estimativa do progresso genético após oito ciclos de seleção recorrente para produtividade de grãos do feijoeiro
}

\begin{abstract}
RESUMO - O objetivo deste trabalho foi estimar o progresso genético após oito ciclos de seleção recorrente visando à obtenção de linhagens de feijão com alta produtividade. A população base foi obtida de dez genitores diferindo em vários caracteres. Atéo momento foram realizados oito ciclos seletivos. Em cada ciclo o processo de seleção continua após a recombinação, até a obtenção de linhagens, que são então avaliadas mais intensivamente, juntamente com linhagens de outros programas no experimento de avaliação de linhagens elites. Para estimar o progresso genético foram utilizados os dados das avaliações dessas linhagens em cada ciclo ao longo desses anos. No total foram envolvidos dados de 42 experimentos nas semeaduras realizadas nos meses de Fevereiro, Julho e Novembro, por dois anos, nos oito ciclos seletivos. A estimativa do progresso genético de 3,3\% por ciclo possibilita inferir que a seleção recorrente para a produtividade de grãos é eficiente.
\end{abstract}

Palavras-chave: Melhoramento de plantas, genética quantitativa, Phaseolus vulgaris $L$.

\section{REFERENCES}

Almeida LD'A, Leitão Filho HF and Miyasaka S (1971) Características do feijão carioca, um novo cultivar. Bragantia 30: 33-38.

Amaro GB, Ramalho MAP, Abreu AFB and Silva FB (2007) Phenotypic.recurrent selection in the common bean (Phaseolus vulgaris L.) with carioca-type grains for resistance to the fungi Phaeoisariopsis griseola. Genetics and Molecular Biology 30: $584-588$.

Barron JE, Pasini RJ, Davis DW, Stuthman DD and Graham PH (1999) Response to selection for seed yield and nitrogen $\left(\mathrm{N}_{2}\right)$ fixation in common bean (Phaseolus vulgaris L.). Field Crops Research 62: 19-128.

Carneiro JES, Ramalho MAP, Abreu AFB and Gonçalves FMA (2002) Breeding potential of single, double and multiple crosses in common bean. Crop Breeding and Applied Biotechnology 2: $515-524$.
Hallauer AR (1992) Recurrent selection in maize. Plant Breeding Reviews 9: 115-179.

Koeyer DL, Stuthman DD, Fulcher RG and Pomeranke GJ (1993) Effects of recurrent selection for grain yield on oat kernel morphology. Crop Science 33: 924-928.

Matos JW, Ramalho MAP and Abreu AFB (2007) Trinta e dois anos do programa de melhoramento do feijoeiro comum em Minas Gerais. Ciência e Agrotecnologia 31: 1749-1754.

Menezes Júnior JAN, Ramalho MAP and Abreu AFB (2008) Seleção recorrente para três caracteres do feijoeiro. Bragantia 67: 833-838.

Ramalho MAP, Abreu AFB and Santos JB (2001) Melhoramento de espécies autógamas. In Nass LL, Valois ACC, Melo IS, Valadares-Inglis MC (Eds.) Recursos genéticos e melhoramento de plantas. Fundação MT, Rondonópolis, p. 201-230. 
Ramalho MAP, Abreu AFB and Santos JB (2005) Genetic progress after four cycles of recurrent selection for yield and grain traits in common bean. Euphytica 144: 23-29.

Ramalho MAP and Abreu AFB (2006) Cultivares. In Vieira C, Paula Júnior TJ, Borém A (Eds.) Feijão. Editora UFV, Viçosa, p. 415-436.

Ranalli P (1996) Phenotypic recurrent selection in common bean (Phaseolus vulgaris L.) based on performance of $\mathrm{S}_{2}$ progenies. Euphytica 87: 127-132.

Rangel PHN, Zimmermann FJP and Neves PCF (1998) Estimativas de parâmetros genéticos e resposta à seleção nas populações de arroz irrigado CNA IRAT 4 PR e CNA IRAT 4 ME. Pesquisa Agropecuária Brasileira 33: 905-912.

SAS Institute (2000) SAS/STAT User's guide: version 8. SAS Institute, Cary.
Silva FB, Ramalho MAP and Abreu AFB ( 2007) Genetic progress after five cycles of phenotypic recurrent selection for early flowering of carioca common bean. Annual Report of the Bean Improvement Cooperative 50: 29-30.

Singh SP, Terán H, Muñoz CG and Takegami JC (1999) Two cycles of recurrent selection for seed yield in common bean. Crop Science 39: 391-397.

Sumarno and Fehr WR (1982) Response to recurrent selection for yield in soybeans. Crop Science 22: 295-299.

Wang XW, Lai JR, Fan L and Zhang RB (1996) Effects of recurrent selection on populations of various generations in wheat by using the Tai Gu single dominant male-sterile gene. Journal of Agricultural Science 126: 397-402.

Werner BK and Wilcox JR ( 1990) Recurrent selection for yield in Glycine max using genetic male-sterility. Euphytica 50: 1926.

Wilcox JR (1998) Increasing seed protein in soybean with eight cycles of recurrent selection. Crop Science 38: 1536-1540. 